\title{
Strongyloidiasis and chronic urticaria
}

\author{
A. C. CorsinI \\ M.D., PhD. \\ Department of Microbiology and Immunology, University of Campinas-UNICAMP, 13.100, \\ Campinas, Brazil
}

\begin{abstract}
Summary
Two patients with strongyloidiasis developed chronic urticaria. The cases provide support for inappropriate interactions of the effector mechanisms in helminthiasis resulting in urticaria in man.
\end{abstract}

\section{Introduction}

Strongyloides stercoralis (Bavay, 1876) is an important cosmopolitan helminth parasite. Human infection varies in regions throughout the world, being heavier in the tropics (Pessoa, 1972). The disease (Cochin China diarrhoea) varies also from mild intestinal discomfort to severe malabsorption syndromes and invasion of the peritoneal cavity and abdominal organs. Fatal cases have been observed, particularly in undernourished children and/or in immuno-suppressed patients (Civantos and Robinson, 1969; Paes, Chieffi and D'Andretta; Neto, 1979; Purtillo, Meyers and Connor, 1974; Rivera et al., 1970). Although intestinal symptoms predominate, unusual bronchopulmonary involvement may be present as well (Rassiga, Lowry and Forman, 1974).

Skin manifestations in strongyloidiasis have been described as linear, erythematous urticarial weals restricted to local invasions of the migrating larva currens (Gill, Bell and Reid, 1977; Gill and Bell, 1979). However, besides the strongyloid creeping eruption, non-specific urticaria has also been described in chronic strongyloidiasis (Grove, 1980).

In this paper, two patients with strongyloidiasis and chronic urticaria are presented. Possible mechanisms involving eosinophils, IgE, mast cells and chronic urticaria in helminthiasis are discussed.

\section{Case reports}

Case 1

A 29-year-old man complained of urticaria. He had been well until 5 months before, when an urticaria characterized by erythema and flare-up weals developed after eating at a barbecue. The lesions were pruritic beginning one $\mathrm{hr}$ after ingestion of any food particularly meat, milk and beans.
Symptoms were maximal $2 \mathrm{hr}$ after meals, fading thereafter.

He was under a restricted diet and severe watch but was unable to correlate any particular food or drug with his distress. The symptoms were partially relieved with a combination of clemastine and dexamethasone but worsened with D-chloropheniramine and betamethasone.

Physical examination was normal except for a generalized erythema with several weals varying in size from $2 \times 2$ to $10 \times 10 \mathrm{~mm}$, particularly on the chest and abdomen. The weals were bigger on the neck.

A blood sample examination revealed $21 \%$ eosinophils $\left(1827 / \mathrm{mm}^{3}\right)$. Neutrophils, lymphocytes and monocytes were within normal range. Numerous larvae of $S$. stercoralis and cysts of Giardia lamblia were detected in the faeces.

\section{Case 2}

A 21-year-old man complained of transient pruritic weals lasting 3-4 hr, and subcutaneous nodules on his chest and shoulders over 3 months. The condition usually worsened with ingestion of meat particularly pork. There was not, however, any timing relation between the meals and appearance of the lesions. He had also been treated with betamethasone and cyproheptadine without any benefit.

Physical examination was normal except for the erythematous eruptions varying in size and shape from 5 to $10 \mathrm{~mm}$ diameter confined to the neck and shoulders. No subcutaneous nodules were detected.

A blood sample examination disclosed $11 \%$ eosinophils $\left(693 / \mathrm{mm}^{3}\right), 9 \%$ monocytes $\left(567 / \mathrm{mm}^{3}\right)$ and normal numbers of neutrophils and lymphocytes. Numerous larvae of $S$. stercoralis were detected in the faeces.

The patients were treated orally for 4 days with thiabendazole $2 \mathrm{~g} /$ daily as one single administration at bed time. They had relief of symptoms after the first dose and were symptom-free 3 days after. Physical examinations were normal on the 4th day. 
They have been followed-up for 8 months with no recurrence of the urticaria. Faecal examination has also been negative during this period.

\section{Discussion}

There is a complex host immune response to parasitic infection due probably to the complex antigenic structure of the parasite and also to several effector mechanisms triggered by the host (Mitchell, 1979).

As a consequence, reinfection with the same parasite or a closely related one is difficult to achieve but this has been demonstrated in several experimental models, particularly with helminths (Mitchell, 1979). The surface of parasitic nematodes is immunogenic to the host and elicits a specific immune response at each stage of the life cycle of the parasite. In addition, complement (C) may be activated and effector cells such as eosinophils make the parasite vulnerable to immune lysis (Mackenzie, Preston and Ogilvie, 1978).

Such experimental data help to explain the well known clinical observation of the association between eosinophilia, helminthic infection and immediate-type hypersensitivity. IgE, mast cells, the $\mathrm{C}$ system and eosinophils evolve in an efficient effector arm of the immune response towards helminths (Kay, 1979).

The chronic urticaria of the present two patients represents an abnormal reaction to multiple triggering factors such as helminthiasis and diverse mechanisms and mediators (Nagy and Klass, 1979). However, the association in these patients between the ingestion of protein-rich foods and the worsening of the allergic symptom was striking. This may be an example of the inappropriate interaction of the effector mechanism mast cell/IgE/eosinophils resulting in 'allergies' (Kay, 1979). The immune response elicited by the parasite, although highly efficient for host protection against reinfection and probably, in the case of $S$. stercoralis, to the invading larvae, triggered unpleasant reactions in parallel. This could explain the classical strongyloid creeping eruption described by Gill et al. (1977).

The present patients did not, however, show those serpiginous eruptions resembling cutaneous larva migrans, but they developed fixed non-migrating, round weals typical of non-specific urticaria as previously described (Grove, 1980). The authors consider, therefore, the possibility of cross-reactions between parasitic antigens and inhalants or ingestants particularly in atopic patients (Kay, 1979), as the mechanism responsible for the nonspecific urticaria of chronic strongyloidiasis.

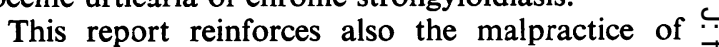
prescribing corticosteroids for any 'allergic' mani- $\overrightarrow{\overline{\vec{\rho}}}$ festation. This argument is stronger for strongy- $\overrightarrow{0}$ loidiasis since corticosteroids may facilitate the invasion of the infective larvae (Rivera et al., 1970; Gill and Bell, 1979). It also provides some clues to the complex host-parasite relationship in man and points to the necessity of a better understanding and measurement of the allergic response in helminthic infection.

\section{Acknowledgments}

I thank Dr A. F. Pestana de Castro for his help.

\section{References}

Civantos, F. \& Robinson, M.J. (1969) Fatal strongyloidiasis $\infty$ following corticosteroid therapy. American Journal of $\mathbb{N}$ Digestive Diseases, 14, 643.

GILL, G.V. \& BELL, D.R. (1979) Strongyloides stercoralis 을 infection in former Far East prisoners of war. British Medical Journal, 2, 572.

Gill, G.V., Bell, D.R. \& ReID, H.A. (1977) Strongyloidiasis $\frac{7}{O}$ in ex-Far East prisoners of war. British Medical Journal, $1,1007$.

Grove, D.I. (1980) Strongyloidiasis in Allied ex-prisoners of war in South-East Asia. British Medical Journal, 280, 589 N

KAY, A.B. (1979) The role of the eosinophil. Journal of. Allergy and Clinical Immunology, 64, 90.

Mackenzie, C.D., Preston, P.M. \& Ogilvie, B.M. (197\&) Immunological properties of the surface of parasitic $\bar{\partial}$ nematodes. Nature, 276, 826.

Mitchell, G.F. (1979) Effector cells, molecules and mech- 응 anisms in host-protective immunity to parasites. Im- Q munology, 38, 209.

NAGY Jr, S.M. \& Klass, M.R. (1979) Treatment and evaluation of acute and chronic urticaria. In: Evaluation and Management of Allergic and Asthmatic Diseases, 1st edn, p. 189. (Ed by Gershwin, M.E. \& Nagy Jr, S.M.), Grune \& Stratton Inc., New York.

Paes, R.A.P., Chieffi, P.P. \& D'Andretta Neto, C. (1979) Estrongiloidiase disseminada de evolução fatal em crianças desnutridas. Apresentação de dois casos. Rev- $\frac{}{3}$ ista do Instituto Adolfo Lutz, 39, 171.

PessoA, S.B. (1972) Parasitologia Médica, 8th edn., p. 599. $\bigcirc$ Guanabara Koogan S.A., Rio de Janeiro.

Purtillo, D.T., Meyers, W.M. \& ConNor, D.H. (1974) Fatal strongyloidiasis in immunosuppressed patients. American Journal of Medicine, 56, 488.

Rassiga, A.L., Lowry, J.L. \& Forman, W.B. (1974) Diffuse pulmonary infection due to Strongyloides stercoralis. Journal of the American Medical Association, 230, $436 . \quad \mathrm{G}$

Rivera, E., Maldonado, N., Veléz-Garcia, E., Grillo, ’ A.J. \& MalareT, G. (1970) Hyperinfection syndrome with $\mathrm{O}$ Strongyloides stercoralis. Annals of internal Medicine, 72, $\mathrm{W}$ 199. 